Michael Schudson,

Distinguished Professor of Communication,

University of California, San Diego and

Professor of Communication,

Graduate School of Joumalism,

Columbia University

\title{
New Technologies and Not-So-New Democracies
}

\begin{abstract}
To understand the impact of new information technologies on democracy, one needs to understand both technology and democracy. This article will comment on the importance of recognizing variety among new technologies and their rapidly changing nature, but its primary focus is on outlining a set of different models of democratic citizenship on which technology might have an impact.
\end{abstract}

Assessing the impact of new media on democracy makes one dizzy. Regardless of how much we would like to be clear-headed, it is simply not possible. The world is spinning us around so swiftly and the media changing so rapidly - even blending into one another - that a clear vision of where we are and where we may be headed remains unattainable.

Merely discerning who 'we' refers to in relation to the new media is hardly a simple task. There is, of course, a much-discussed digital divide separating the human race into those who have access to computers and those who do not. But this is merely the beginning. There is also a communicative divide. Some people with access to computers do not use them to communicate with other individuals, i.e. they do not use email or the Internet extensively. In the United States, there is a cable television divide between households subscribing to cable television and receiving 100 channels and other households that only have over-the-air television with four or five channels. There is a divide between cable households subscribing to the pay or 'premium' channels, e.g. $\mathrm{HBO}$, and those that do not. A segment of the educated American elite were practically addicted to the $\mathrm{HBO}$ series The Sopranos, and a younger, more female segment of that group likewise became dependent upon Sex and the City, while others, without premium channels, had to act as if they knew what the 'insiders' were talking about. The new media thus define numerous divides; however, they are difficult to name or label on the grounds that they are constantly changing. Several technological generations ago - that is, in the year 2000 - political scientist Bruce Bimber wrote:

\begin{abstract}
"Increasingly, the Web, electronic mail, television, recorded music, cellular phone service, and a variety of other portable electronic technologies, from personal organisers to automobile navigation systems, will merge. As this technological evolution occurs, what is 'the Internet' and what is not will become ever more intricate and, in some cases, unimportant" (Bimber 2000: 330).
\end{abstract}

For Bimber, 'the Internet' represents a problematic concept. We do not know where it begins or ends. We do not know how to discuss its impact. We do not possess an adequate understanding of why it has developed in different ways in different countries (but see Freeman 2003). Consider a thought experiment concerning the impact of new information and communication technologies on our world. Could one reasonably assess developments in the production of news over the past thirty or forty years without attending to the technological changes that have affected news? Could you omit technology and continue to be able to identify most of the important 
events that have occurred in the production, textual character and public comprehension of news? This depends on what you judge the most important developments to be. I would say that the most important developments are the following:

1. a decline in the linkage between political parties and journalists (in Europe, not in the United States);

2. a significant expansion of what counts as news from institutional politics to news regarding society and social trends, private life, health, sexuality, medicine, and the affairs of ordinary people, including women and ethnic and racial minorities;

3. a growing irreverence, aggressiveness, and skepticism in the coverage of politics, politicians, and government;

4. a blend of information and entertainment in the presentation of news; and

5. the 24-hour news cycle in which news organizations post new stories around the clock on their websites or their 24hour radio and television stations.

Of these important developments, only the latter is intrinsically related to new technologies, most of all the technology (and economics) of cable television. For the United States, the development of $\mathrm{CNN}$, subsequently followed by its cable news rivals, as well as the expansion in the 1970 s and 1980 of local television news as a profit center, had much more to do with the accelerated pace of news-gathering than did Internet accessibility. But with respect to the other four features of change in the news, word processors in the newsroom, cell phones, computer-assisted reporting, hand-held cameras, videophones, or the global availability of the news output of any newspaper with a website were not necessary factors at all. Considering how the character of the news product has changed since the 1960 , technology is simply not decisive.

But what is? In my view, the decisive factor is a decline in the cultural authority of conventional institutions of power; a general flattening-out or democratization of cultural authority. It is not that a prison guard or police officer or navy admiral has less command of tools of violence today than yesterday; however, the authority of their voices, the willingness of civilians to defer to whatever they say, to trust that it is benevolent and wise, has dimmed (Friedman 1999).

\section{"We think we know what democracy is, as it appears as though we have always had it."}

In much of the discussion regarding the impact of new technology on democracy, people often imagine that the notion of democracy and the best practices of democracy are constants and technology is the variable whose effect we must attempt to establish. It is difficult not to think in this manner. Democracy is older than we are, but every adult today is older than the Internet. We think we know what democracy is, as it appears as though we have always had it. But democracy as both ideal and practice has changed over time and has varied significantly across nations. Of course, this is elementary; it is 'Introduction to Comparative Political Institutions'. But its importance is far-reaching. Without understanding this, we cannot make progress in thinking through the place of new technologies in democracy. Understanding the impact of new technologies on democracy first of all requires that we understand democracy - and this must include recognizing that any particular national democracy we consider is not 'generic democracy', but a distinctive brand of democracy. In the American case, which will be my example here, the character of democracy has changed dramatically on at least three occasions, and most of the key features of what Americans tend to think of as ideal democracy - features that organize the American imagination about how new technologies can and should serve democracy - date to the Progressive Era, the period from 1890 to 1920.

In pursuing this topic, I follow - but also take issue with - Jürgen Habermas in his path-breaking explorations of the public sphere and its history. Habermas' work inspired me to raise questions regarding the constitution of the public sphere and the strength with which it was enacted in different eras of U.S. history. I began looking for ways to evaluate how closely American civic life approached the public sphere ideal in different periods. What Habermas had not prepared me to understand is how rigid 
and ultimately ahistorical that question is. What changed over two centuries was not only practices of political speech and political participation, but also ideals of what political speech and participation ought to be.

The changes in the ideals, concepts and cultural climate for public life are what I want to discuss here. Different eras in American political history have called forth contrasting ideals of what democracy should be and what a citizen in a democracy ought to be like. This argument is fully laid out in my book, The Good Citizen (1998). I cannot present it in its entirety, but a group of high school teachers suggested to me that my position is accurately and easily summarized by using The Simpsons as a point of reference. What contemporaries honored as the ideal citizen or the normatively desirable citizen has differed across four eras in American history, each of which can be represented by a different member of the Simpson family.

\section{The Marge Simpson Era}

The colonial era through the Washington and Adams Administrations offers a model of what I refer to as the deferential citizen. The ideal citizen in this era was a person who recognized the leaders of the community and voted for them, deferring on any specific issues to their judgment. Picture Marge Simpson, conscientious, moral, but normally knowing her place - deferential. In the 1700 , voter turnout was low; campaigning was discouraged; voters were supposed to measure candidates in terms of their character and social standing, not their political ideas; and voluntary organizations were welcome in private life but regarded with suspicion if they ventured to offer opinions on public affairs.

Imagine yourself a voter in the world of colonial

"Different eras in American political history have called forth contrasting ideals of what democracy should be and what a citizen in a democracy ought to belike."

Virginia, where George Washington and Thomas Jefferson learned their politics. As a matter of law, you must be a white male owning at least a modest amount of property. Of this group, turnout was 40-50 percent in the 1780 s. Voting was required by law and there were sub- stantial fines for not voting, though this law was rarely enforced. Your journey to vote may take several hours, since there is probably only one polling place in the county. You might spend the night at the county seat - if this was George Washington's district, there might be supper and a ball at the Washington's, with spirits flowing freely (during an election in 1758, it is estimated that George Washington provided a quart and a half of liquor per voter). As you approach the courthouse, you see the sheriff supervising the election flanked by the candidates for office.

You approach the sheriff, announce your vote in a loud voice, audible to all those around you, and then you go over to the candidate for whom you have voted and shake hands in a ritual of social solidarity. Your vote has been an act of assent, restating and reaffirming the social hierarchy of a community in which no one but a local notable would think of standing for office, where voting is conducted entirely in public view, and where voters are ritually rewarded by the gentlemen they favor.

In such a world, what information did a voter require? Colonial education aimed to instill religious virtue, not to encourage competent citizenship. Schooling and reading were understood to be instruments of inducting citizens more firmly into the established order. This is important to have straight at the outset: a concept of an 'informed citizen' was simply not a leading idea for the founders. The whole of the citizens' informational obligation was to turn back the ambitious and self-seeking at the polls; however, the citizens were not supposed to evaluate public issues themselves; that was what representatives were there for.

\section{The Homer Simpson Era}

In the early 1800 , as mass-based political parties emerged to replace the party-phobic world of the founders, the normative good citizen shifted from the deferential man of property to the democratic, enthusiastic partisan. Where the founding generation frequently spoke of 'democracy' with distaste and understood themselves as the builders of a republican form of government that would accommodate but not surrender to forms of popular rule, the term 'democracy' was held aloft as a banner in the first half of the nineteenth century and appeared to sweep all before it. Modes of civic participation multiplied, as did the varieties of people welcomed as 
participants. But of all the new, participatory organizational forms - from democratized churches to temperance reform associations to abolitionist clubs - the political party became the central avenue of civic engagement. Parties involved masses of citizens in local and regional nominating conventions, and many more in the barbecues, picnics, torchlight processions, pole raisings, glee clubs, brass bands, hooliganism, and mass mobilization on Election Day. This festive politics proved remarkably sturdy and popular for most of the nineteenth century. Homer Simpson would have fit right in. Fellowship and partisan rivalry were often embraced for their own sake, regardless of issues or ideologies; the tavern's social life - as opposed to the intellectuallife of the party platform - was the basis of political identification.

On Election Day, the parties hired tens of thousands of workers to get out the vote and stand near the polling place to hand out the 'tickets' they have printed. The voter approached the polling place, took a ticket from one of these 'ticket peddlers' and went up to the voting station to deposit his ticket in the ballot box. He did not even need to look at it. He did not mark it in any way. Clearly, he did not need be literate. Very often, once he had voted, he received payment for his effort. In New Jersey in the 1880 s, as many as one-third of the electorate expected payment for voting, usually an amount between $\$ 1-3$ (Reynolds 1988: 47). It is hardly surprising that this was the era of the highest voter turnout in American history, with 70-80 percent turnout (outside of the South) very common.

What did a vote express in those days? James Bryce, a British scholar and statesman who served for some time as Ambassador to the United States, wrote in 1888 that he asked of the leading American political parties, "What are their principles, their distinctive tenets, their tendencies? Which of them is for free trade, for civil service reform, for a spirited foreign policy?" And he answered:

"This is what a European is always asking of intelligent Republicans and intelligent Democrats. He is always asking because he never gets an answer. The replies leave him in deeper perplexity. After some months the truth begins to dawn upon him. Neither party has anything definite to say on these issues; neither party has any principles, any distinctive tenets" (Bryce 1891: 20).

Modern historians tend to agree with Bryce. Political historian Paula Baker writes, "Party politics in this period may be considered only marginally political, in the sense that it lacked a direct connection with government or policies" (Baker 1984: 181).

This is the large, uncomfortable fact of late nineteenth century politics to couple with the exceptional record of voter participation. The question of 'who' votes cannot be separated ultimately from the question of 'what voting means'. We may be impressed that a far greater proportion of the eligible voters went to the polls in presidential elections than today, but why did they go? Not out of any strong conviction that the party offered better public policies; parties tended to be more devoted to distributing offices than to advocating policies. The party was related more to comradeship than to policy, it was more an attachment than a choice, something similar to a contemporary loyalty to a football team. Voting was less a matter of conviction or principle than a statement of affiliation. Drinks, dollars and drama brought people to the polls, and, more than that, social connection - rarely anything more elevated.

\section{The party was related more to comradeship} than to policy, it was more an attachment than a choice, something similar to a contemporary loyalty to a football team."

\section{The Lisa Simpson Era}

The period 1890-1920 brought a flock of important reforms, unmatched anywhere else in the world, to assault party control and the enthusiastic mode of civic participation that it fostered. State-printed ballots replaced party-printed tickets; nonpartisan municipal elections in some cities replaced machine-dominated urban party politics; the initiative and referendum and the direct election of senators weakened the party as the link between citizen and state. The party-subsidized and partydirected newspapers gave way to an independent-minded commercial press. All of these developments provided the institutional groundwork for an ideal of an informed, rather than blindly partisan, citizen. This 
model of citizenship was well suited to single-issue and policy-oriented interest groups, from the Grand Army of the Republic and its advocacy of veterans' pensions to the women's suffrage movement. In fact, in the wake of the achievement of women's suffrage, the League of Women Voters emerged as a leading voice of information, informed policy discussion and debate, and a form of civic engagement determinedly at arm's length from party politics.

\section{"The center of political gravity shifted from party to voter:}

Lisa Simpson would have been proud. Even the parties developed a more informational style of campaigning, moving from parades to pamphlets as they adopted what one historian terms an 'educational' style of politics in the 1890 s and thereafter (McGerr 1986: 1241). The Progressive Era did not destroy political parties, but in its distaste for the nineteenth century style of party politics, succeeded in promoting a new ideal of a rational, issue-centered, educated, and informed citizenry. Political parades remained in 1900 and 1904, but they were rapidly dying off. By 1908 , the occasional parade was described as "simply a curiosity, a pale reminder of an earlier time" (New York World 1908). Bannerraisings and pole-raisings tapered off. The parties stopped hiring glee clubs and brass bands for rallies.

As parties invested less in rallying their own loyal followers and moved toward persuading uncommitted voters or 'floaters', there came to be an incentive for policy-oriented moral entrepreneurship. If party loyalty could be sustained by Fourth of July rhetoric, tradition, the promise of jobs, and social pressure on Election Day, party success in the new era had to turn to something new - a party program promising good policies more than good jobs. The reforms of the day, in other words, forced parties to redefine their own identities and to reconceive political substance and the very purpose of the state. Reform to campaign practices was one of a family of reforms and social changes that altered political communication profoundly. People now had to register to vote. Election fraud became more difficult. Bribery declined. Newspapers became less partisan and a new emphasis on informed voters led some states, particularly in the west, to provide voter information guides to all voters by the 1920 s. Today, in states such as California or Oregon, these guides are provided to every registered voter at government expense and may be hundreds of pages long.

One of the most symbolically loaded reforms was ballot reform. Adopted almost everywhere in a few short years, supported by labor as well as by upper-class genteel reformers, the 'Australian ballot' deserves special attention. The United States borrowed the way it votes from a mid-nineteenth century reform pioneered in Australia. The Australian ballot represented a shift from party-provided to state-provided ballots. It represented a change from a system in which citizens made their voting choices (by accepting a ticket from a party's ticket peddler) in full public view to one in which they marked a ballot in privacy. The center of political gravity shifted from party to voter. Not incidentally, this demanded of voters for the first time some degree of literacy to play their role in the election drama. Voting changed from a social and public duty to a private right, from a social obligation to the party enforceable by social pressure to a civic obligation or abstract loyalty, enforceable only by private conscience.

The ideal citizen in American practice moved from the deferential citizen of the founders to the loyal partisan citizen of the nineteenth century to the informed citizen of the Progressive Era - from Marge to Homer to Lisa. The 'informed citizen' ideal imposed more challenging cognitive tasks on prospective voters than ever before. It constituted the language by which Americans continue to measure politics. With "the informed citizenry' newly enshrined, there was a new mechanism - literacy tests - for disenfranchising African-Americans and immigrants, and there was a new rationale for an enduring tradition of hand-wringing over popular political ignorance.

In an informative study a decade ago, historian Richard D. Brown traced the idea of an informed citizenry in America from 1650 to the Civil War. Although he found glimmerings of the idea as early as the mid-15oos in England, the idea was by no means dominant or well developed. Even the Glorious Revolution's Bill of Rights in 1688 guaranteed freedom of speech only in Parliament, not outside of it. Theories of education in Britain and 
colonial America favored the education of gentlemen, not the general population. Where charity schools were established to educate the common people, the object was to teach them "to value subordination and deference over the siren calls of demagogues" (Brown 1996: 44). Until the $1760 \mathrm{~s}$, Brown writes, the idea of an informed citizenry remained 'inconsequential' (Brown, 1996: 49) in the American colonies. In the revolutionary generation, praise of the wide diffusion of knowledge and a free press had a 'ritualized' (Brown 1996: 89) ring to it, in Brown's terms.

The founders advocated an informed citizenry as a defensive gesture - urging knowledge as a safeguard against demagoguery, but rarely defining what positive knowledge citizens ought to acquire. In the early nineteenth century, informing citizens became a task for advancing a disciplined and productive work force, for assimilating immigrants to American life, and for cultivating law-abiding citizens - but rarely was educating voters articulated as a prime objective. That voters should be attentive, informed, and literate; that the press should provide objective information rather than partisan cheerleading; and that government itself should invest in institutions rendering it easier for voters to participate rationally in politics - all of this is a product of the period from the 1880 s to the 1920 s.

\section{The Bart Simpson Era}

And Bart? What does Bart represent? Bart is the antiauthoritarian, individualist, irreverent, rights-claiming citizen of the era that the civil rights movement ushered in. It would be a mistake to perceive Bart as the anti-citizen. Instead, he offers another ideal-type figure of what good citizenship can look like.

To some degree, Bart simply plays pure id to Lisa's pure superego, his impulse to her conscience; but that is not the entire story. Bart, like the representatives of so many of the liberation movements that have powered American politics since the civil rights movement, stands up for his rights, making aggressive and often self-serving claims on the body politic. However, to claim a right is not merely to grab what you want; it is an implicit agreement to make a case on the basis of common principles, common aims and common laws. Whether it is a pro-life or pro-choice movement, environmentalism or advocacy for livable wage ordinances, supporters of a patients' bill of rights or school choice, the politics of the past half-century have increasingly operated through mechanisms on the fringes of the parties and not always readily linked to them. These social movements have spawned a bewildering array of political approaches and they have enlarged - exploded - the arena of politics itself. As recently as 1961, political scientist Robert Dahl observed that most people have little interest in politics; their primary activities are not politics but "food, sex, love, family, work, play, shelter, comfort, friendship, social esteem, and the like" (Dahl 1961). It is easy to see that all of these topics have been politicized -- even 'self-esteem', and not only in California (Nolan 1998: 152-161). This is Bart's world, not entirely serious or sober or responsible, playful and brash and irreverent, sometimes charming and sometimes gross, breaking with convention.

\section{"Americans rarely understand how new the emphasis on rights in American politics actually is."}

A part of this highly individualistic and contentious style of politics is an emphasis on the courtroom as a political arena. Americans rarely understand how new the emphasis on rights in American politics actually is. After all, the Bill of Rights became part of the U.S. Constitution in 1791, and the struggle against Britain in 1776 concerned the right to political representation. However, the Bill of Rights did not apply at all to the states until the 14th Amendment in 1868, and it was not until the 1920 s that the Supreme Court began to interpret the First Amendment to offer strong protection to dissident speech. Until the late 1930s, the Supreme Court was far more concerned with 'powers' than with 'rights', i.e. its decisions focused on the relative authority of state and federal governments and only in rare instances touched on the claims of individuals against the state (Schudson 1998: 245-264). Changes in legal philosophy in the 1930 and 1940 s and, even more, the emergence of the Warren Court in the 1950 s and the aggressive legal campaign for civil rights sponsored by the NAACP put the courts on the map of citizenship for the first time. Suing, as well as voting, became a path of civic engagement.

While Bart Simpson might appreciate the adversa- 
rial quality of the courtroom, he would not readily take to its civility and structure. The Bart Simpson era of citizenship is in part about rights, but it is just as much about the expressiveness of the protests for those rights, including sit-ins and mass demonstrations. It includes shouted expletives, such as the jacket worn by Robert Paul Cohen in a Los Angeles courthouse in 1968 on which the words, "Fuck the Draft", were printed. It includes the black armbands worn by high school students in Des Moines, Iowa in 1969 in protest of the Vietnam War, armbands that led to their suspension from school. Cohen sued for his First Amendment right to speech, ultimately taking his case to the Supreme Court, where he won. The young people in Des Moines did likewise, also winning in the Supreme Court. What makes them part of the Bart Simpson Era is the irreverence, chutzpah and aggression of their claims on the public's attention. This era features the ornery, the unpleasant, the isola-

"The dramatic power of Sheehan's protest came primarily from its non-mediated quality, from her insistence on a face-to-face meeting with President Bush."

ted, the anarchic leadership of a Ralph Nader or the money-grubbing lawyers who represented clients for years in suits against the tobacco companies. It includes the likes of Cindy Sheehan, the mother of Casey Sheehan, the 24-year-old soldier who died in the War in Iraq in 2004. Ms. Sheehan kept a vigil outside President George W. Bush's ranch in Crawford, Texas for weeks in the summer of 2005 while he was vacationing there, requesting a meeting with the President. Sheehan inspired scores of others to join her in Crawford, including other mothers of soldiers killed in Iraq, to make their opposition to the war known in the most powerful terms.

Which media of communication serve this era of civic irreverence? Well, you can learn about Gold Star Families for Peace, the organization Cindy Sheehan founded, by going to their Website (www.gsfp.org). You can read about Sheehan in any American newspaper or hear about her in national television news broadcasts. On August 17, 2005, thanks to the Internet and the organizational efforts of moveon.org, the country was dotted with hundreds of local vigils at the same hour in support of Sheehan's vigil in Texas. Not to minimize the importance of the new media here, but the dramatic power of Sheehan's protest came primarily from its non-mediated quality, from her insistence on a face-to-face meeting with President Bush. Her organization had existed for some time. Her public notoriety existed only since she got on a commercial jet from her home in California and flew to Crawford, Texas to put her body on the line. What characterizes her political activism is not a technology but a mood that Bart Simpson would understand very well, as would Thurgood Marshall, Ralph Nader, Martin Luther King, Jr., activists on both sides of the abortion controversy, and many others.

\section{Maggie's future}

A question remains: who or what does Maggie Simpson represent? What model of citizenship will she embody as she grows up? Consider this an open-ended question and not a matter of reclaiming some model from the past. What will matter is what view or views of citizenship and politics she will claim for herself, not what media technologies she will use. It should be apparent that all of the models I have discussed here coexist today, even though they have emerged as dominant ideals in the American political imagination and political practice in different eras. Maggie, like other citizens of the future, is likely to borrow from all of them at different times and in different circumstances.

\section{Discussion}

Too much of the discussion about the impact of the new media on politics appears sterile and thin. Why should this be? It is easy to show that networks serve political activism. If you study new social movements, you find they make use of new technologies - but then, who doesn't? This is hardly sufficient evidence to demonstrate that the Internet promotes democracy.

Suppose, on the other hand, you want to demonstrate that the effects of new technologies on democracy are minimal. Then you just show that social networking preceded new technologies - and, of course, it did; or that powerful institutions use new technologies to greater effect than resource-poor social groups and, of course, they do; or that politics as usual remain largely untouched by new technologies. It is difficult to see how President Bush's Iraq policy - or Germany's or France's 
or Britain's or Israel's or Saudi Arabia's - have been altered by new information technologies. In fact, this is so preposterous a notion that I do not think anyone has even seriously suggested it. Of course, the leakiness of communication has embarrassed governments, with Abu Ghraib the leading instance. In this case, the technological factor was digital photography, which briefly embarrassed the Bush administration and perhaps more lastingly produced a symbol of American indifference to world opinion. However, responses to Abu Ghraib or to the infringement of civil liberties at Guantanamo have taken place in the usual congressional committees and courtrooms, both military and civil, in just the way they always have, cable TV or not, Internet or not.

If there is any kind of politics that the new information technologies have disproportionately enabled, it may be international terrorism. Could Al Qaeda work nearly so well without e-mail and cell phones? Could decentralized guerilla groups coordinate with one another around the globe without these modern forms of communication? It is no surprise that al Qaeda actively uses the Internet - again, who doesn't? But it is plausible to argue that the decentralized, global, and clandestine character of international terrorism makes the Internet a particularly congenial medium (Coll 2005).

The Internet can do some things for democracy and not others. There are obvious reasons for taking the Internet seriously. There are ways in which digital communication "eases personal engagement with others" and so changes "the nature of social transactions" (Bennett 2004). We know from scores of examples that activist groups can nimbly employ cyberspace to advance their ends, that political campaigns can effectively use the Internet for fundraising, and that varieties of insurgent organizations can use the Internet not only to publicize their work but to bring people together, at least episodically, in face-to-face meetings. We know that organization by Internet allows people to assemble and disassemble with little cost and it allows organizational structures (such as moveon.org) to shift from organizing on one issue to another issue with little slippage or loss along the way.

Philip Agre has argued that the effect of the Internet on politics ought to be understood as one of amplification. He approvingly cites Craig Calhoun's observation that the Internet's short or medium term impact "will be to allow us to do more of the things we were already organized and oriented to do." For Agre, "the Internet creates little that is qualitatively new; instead, for the most part, it amplifies existing forces." He urges us to be attentive to the power of existing institutions to keep doing what they have been doing (Agre 2002). In this, Agre is neither optimist nor pessimist; rather, he is a cyber-pragmatist or cyber-realist. His view is consistent with data on how people who use the Internet use it. An EU survey of Internet users in 2000 found that 69 percent use e-mail, 47 percent have used the Internet for online training and education, 47 percent for shopping, 28 percent for playing games, and 23 percent for job searching. Roughly 15 percent have visited government Websites, 10 percent political party websites, and a smaller percentage have used the Internet for other political purposes (Barney 2004: 129).

\section{"If there is any kind of politics that the new information technologies have disproportionately enabled, it may be international terrorism."}

\section{Conclusion}

Agre's position, or something like it, appears almost inevitable. Scholar after scholar line up extreme bubbles of optimism concerning the impact of the new information technologies on democracy and the dark gloom of others who perceive the Internet as doing nothing but reinforcing existing inequalities of money, power and status. They all conclude that the truth lies somewhere in between (Barney 2004: 124-126). Surely it does, but more than this, surely our questions must be better and more precisely posed. There are many new technologies, with many differences among them and overlappings across them, and many different ways a person can make use of any one of them. Under these circumstances, how can we speak sensibly of the 'impact of technology' in general? And, as I have attempted to demonstrate, there are also many - or at least multiple - democracies, with sharply different features. We cannot speak sensibly of this thing, democracy, that technology is having an influence on as if it were a simple laboratory rat with one individual no different than the next for our purposes. 


\section{REFERENCES}

Agre, P.E. 2002, Real-Time Politics: The Internet and the Political Process, The Information Society, vol. 18, pp. $311-331$.

Baker, P. 1984, The Culture of Politics in the Late Nineteenth Century: Community and Political Behavion in Rural New York, Joumal of Social History, vol. 18, p. 181 .

Bamey, D. 2004, The Network Society, Polity, Cambridge.

Bennet,, W. L. 2004, 'Communicating Global Activism' in: Van de Donk, W., Loader, B., Nixon, P. and Rucht, D. (eds.), Cyberprotest: New Media, Citizenship, and Social Movements, ROutledge, London.

Bimber, B. 2000, The Study of Information Technology and Civic Engagement, Political Communication, vol. 17, p. 330 .

Brown, R.D. 1996, The Strength of a People: The Idea of an Informed Citizenry in America, 1650-1870, University of North Carolina Press, Chapel Hill.

Bryce, J. 1891, The American Commonwealth, vol. 2 Charles H. Sergel, Chicago.

Coll, S. 2005, "Terrorists Turn to the Web as Base of Operations', Washington Post, Aug. 7, A-1.

Dahl, R. 1961. Who Governs?, Yale University Press, New Haven.

Freeman, L.A. 2003 , 'Mobilizing and Demobilizing the Public Sphere: Mass Media and the Internet in Japan', in Schwartz, F,J. \& Pharr, \$.J. (eds), The State of Civil Society in Japan, Cambridge University Press, Cambridge.

Friedman, L.M. 1999, The Horizontal Society, Yale University Press, New Haven.

MeGerr, M. 1986, The Decline of Popular Politics, Oxford University Press, New York.

Munro, W.B. 1912, The Government of American Cities, Macmillan, New York.

New York World, Nov. 2, 1908, 'The Passing of the Parade', p. 6.

Nolan, J. L. Jr. 1998. The Therapeutic State, New York University Press, New York.

Reynolds, J.F. 1988, Testing Democracy: Electoral Behavior and Progressive Reform in New Jersey, 1880-1920, University of North Carolina Press, Chapel Hill.

Schudson, M. 1998, The Good Citizen: A History of American Civic Life, Free Press, New York. 
Anker Brink Lund,

Professor, dr.phil.,

International Center for Business and Politics,

Copenhagen Business School

\title{
Domesticating the Simpsons - Four Types of Citizenship in Monitorial Democracy
}

\author{
Inspired by Michael Schudson, four types of historically informed citizenship, cast \\ in the cartoon characters of the Simpsons, are presented as a promising fra- \\ mework for studies of mediated democracy in network society. The four types of \\ citizenship, however, cannot be imported wholesale. They must be politically do- \\ mesticated and historically amended before application to Danish settings.
}

The citizen is the $\mathrm{X}$ of political calculus: the great unknown without whom it is difficult to justify representative and public opinion-driven democracy. Institutional legitimacy rests upon the argument that ordinary men and women are capable of taking part in communal matters, saturated by social norms defining how individuals are expected to act collectively as good citizens. In current debates - among scholars as well as journalists - $\mathrm{X}$ is discussed primarily in order to document how poorly current affairs live up to the ideals of informed citizenship, loosely defined as a set of deliberative norms partly traceable back to the agora of antiquity, partly to the dawning of the European liberalism, and partly to the American Progressive Era of the early 20 th century.

In this article, I shall challenge this nostalgic view that postulates a historical fall of public man (Habermas 1962; Sennett 1977). We also challenge the futuristic optimism that hails the new technology as a liberator of democratic participation (Grossman 1995; Tsagarousianou \& Tabini 1997). In line with Mazzoleni \& Schultz (1999: 247), we regard political mediatization neither as democratic decline nor as technological emancipation, but rather, as a gradual development whereby "political institutions increasingly are dependent on and shaped by mass media, but nevertheless remain in control of political processes and functions." More specifically, we compare historically constituted types of citizenship in Denmark and the United States of
America in order to demonstrate how X may be segmented and how different groups of citizens interact with the news media over time. The comparative approach places shifting concepts of citizenship at the very core of representative democracy as justifications for public talk and political action, spun by governing elites, framed by professional journalists, and primed by networking niches of everyday life.

In doing so, inspiration has been found in an historically informed typology of American civic life as presented by Michael Schudson $(1998 ; 1999$ \& this journal p. 6-14). Schudson illustrates his sociological framework with characters from the television cartoon series The Simpsons. His four ideal types of citizenship shall be amended and domesticated by drawing upon recent research in Danish media development (Bruhn Jensen 2003; Lund 2004) and supplemented with representative survey data (Lund 2003a; Modinet 2003).

Schudson's main thesis is that historical links between information and democracy as well as citizenship and mass media are hardly as tight as communications scholars tend to make them. Professional news providers are undoubtedly important mediators for public debate; however, neither journalists nor spin doctors are uncontested drivers of civic life. Political communications research should therefore not merely inquire as to what news media do to the masses, but also what different types of citizens do to mediated democracy. 